\title{
Protein Lin-9 Homolog
}

National Cancer Institute

\section{Source}

National Cancer Institute. Protein Lin-9 Homolog. NCI Thesaurus. Code C158451.

Protein lin-9 homolog (542 aa, $\sim 62 \mathrm{kDa}$ ) is encoded by the human LIN9 gene. This protein plays a role in the G1/S transition of the cell cycle. 